\title{
Die missio Dei en die bestudering van die Ou Testament
}

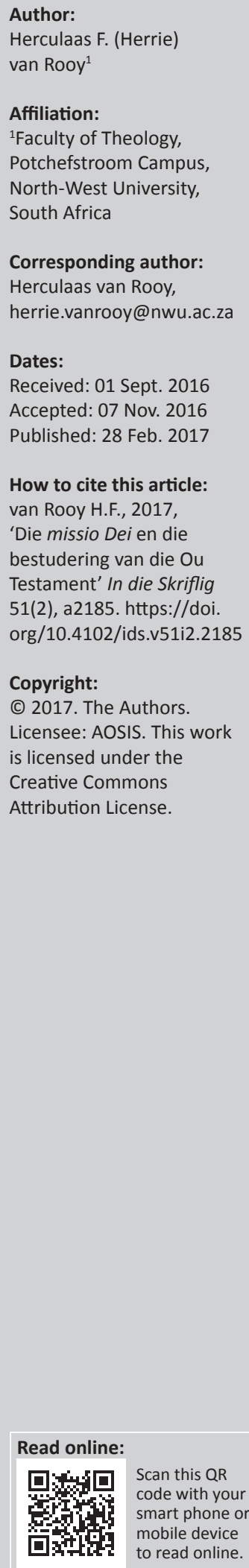

\begin{abstract}
In the recent past the issue of the missio Dei played an important role in the discussions about the mission of the church as God's instrument in the world in missionary work and theological training. This contribution focuses on the study of the Old Testament and its role and message for the mission of the church as well as for theological training. After discussing some aspects of the missio Dei, a number of examples of the use of the Old Testament in this regard are discussed as well as the way the message of the Book of Ezekiel may contribute to understanding the missional task of the church.
\end{abstract}

\section{Inleiding}

Die afgelope 60 jaar is die begrip missio Dei op verskillende maniere geïnterpreteer in die teologiese debat oor die taak van die kerk in die wêreld, oor die verhouding tussen missiologie en die ander teologiese dissiplines, en oor teologiese opleiding. In die lig van die tema van hierdie uitgawe van In die Skriflig/In Luce Verbi gaan hierdie bydrae konsentreer op die Ou Testament en die missio Dei wat die bestudering van die Ou Testament sowel as teologiese opleiding betref. In die eerste gedeelte word enkele tersaaklike opvattings van die missio Dei bespreek. In die volgende gedeelte word 'n aantal studies nagegaan om die voorkoms van die missio Dei in die Ou Testament of gedeeltes daarvan te identifiseer. In die laaste gedeelte word gelet op die bestudering van die $\mathrm{Ou}$ Testament as 'n deel van teologiese opleiding en die verhouding daarvan tot die missio Dei.

\section{Enkele beskouings van die missio Dei}

Georg Vicedom het met sy publikasie Missio Dei. Actio Dei van 1958 'n groot bydrae gelewer om die begrip missio Dei in sendingwerk en missiologie te vestig. ${ }^{1}$ Vicedom (2002:32-33) wys daarop dat die klem in sending vroeër op die gedagte in die Bybel geval het dat sending na die nasies wettig en nodig is. Sending word ook soms verbind aan die opdrag aan die kerk om dissipels van al die nasies te maak, of aan die opvatting dat die Christelike kultuur ver en wyd uitgebrei moet word. Vicedom verkies egter om die begrip missio Dei as uitgangspunt vir sendingwerk te gebruik. Hiervolgens is die kerk net 'n instrument in God se hande, want die missio Dei sê dat sending God se werk is en dat dit in die optrede van God self begrond is. Sending het sy oorsprong daarin dat God die Vader sy Seun na die wêreld gestuur het en die Vader en die Seun die Gees gestuur het (bl. 34). ${ }^{2}$ God se sending van sy Seun en die Gees is 'n uitdrukking van God se werksaamheid in die hede in oordeel en genade (bl. 35-36). Vicedom omskryf die missio Dei soos volg:

Die Missio Dei ist das Werk Gottes, wodurch alles, was er zum Heil der Menschen im Sinne hat, die ganze
Fülle seines Reiches der Erlösung, den Menschen durch seine Gesandten anbieten lässt, damit sie van der
Sünde befreit, dem andere Reich entnommen, wieder ganz in seine Gemeinschaft kommen können. [Die
Missio Dei is die werk van God, waardeur Hy alles wat Hy vir die redding van die mens beplan het - die volheid van
die verlossing van sy koninkryk - deur sy gesante vir die mens aanbied, sodat hulle, weggeneem uit die ander ryk,
weer ten volle die gemeenskap met Hom kan geniet.] (bl. 56, [outeur se vertaling])

Sending is dus die verkondiging van die heilsboodskap deur die totale kerk aan alle mense. As gevolg hiervan het die kerk sowel as die teologie ' $n$ besondere opdrag om uit te voer (bl. 227).

In hierdie verband is Bosch ${ }^{3}$ (1996:389-393) se oorsig in Transforming mission: Paradigm shifts in theology of mission van die begrip missio Dei steeds waardevol. Hy wys op die rol wat Karl Barth gespeel het om sending as 'n handeling van God te beskou (bl. 389). Barth het ' $n$ belangrike invloed op die konferensie in Willingen uitgeoefen waar sending in die konteks van 1.In hierdie artikel is die herdruk van 2002 gebruik.

2.Alle verwysings na bladsye het betrekking op die publikasie wat telkens vooraf genoem word.

3. Hierdie werk van Bosch het in 1991 verskyn, maar die herdruk van 1996 is in hierdie artikel gebruik. 
die Drie-eenheid geplaas is soos ook blyk uit die bespreking van Tennent se standpunt (2010) hieronder. In hierdie benadering is God die Een wat sending onderneem en die kerk 'n instrument (Bosch 1996:390). Bosch wys egter daarop dat die begrip missio Dei ná Willingen verandering ondergaan het. God se sending gaan uit na die hele wêreld. Dit gebeur ook in die niekerklike geskiedenis en nie maar net in en deur die kerk nie (bl. 391). Hierdeur het die konsep 'n wyer betekenis verkry en het die rol van die kerk in die missio Dei kleiner geword. Bosch wil nie van die begrip afstand doen nie, omdat hy sending nie as die uitsluitlike taak van die kerk of mense sien nie, maar as die werk van die drie-enige God.

Tennent (2010:64) plaas sending ook binne die raamwerk van die drie-enige God en werk ' $n$ trinitariese begronding van sending uit in sy boek Invitation to world missions: A Trinitarian missiology for the twenty-first century. Sy basiese uitgangspunte kan in drie stellings wat met die Drie-eenheid verband hou, saamgevat word: God die Vader is die bron, inisieerder en doel van die missio Dei (bl. 75); God die Seun is die verwesenliking van die missio Dei (bl. 82); laastens is die Heilige Gees die bemagtigende teenwoordigheid van die missio Dei (bl. 92). Ott, Strauss en Tennent (2010:65-74) vat dit saam deur te verwys na die sending deur die Vader, die stuur van die Seun deur die Vader, die stuur van die Heilige Gees deur die Vader en die Seun, en die uitstuur van die kerk.

In die lig van hierdie beskouing van sending word daar ook gewag gemaak van 'n missionale hermeneutiek waarmee die Bybel gelees moet word. Flemming (2011:5) omskryf 'n missionale hermeneutiek in sy artikel 'Exploring a missional reading of Scripture: Philippians as a case study' in 'n poging om die Skrif te lees in die lig van God se sending en die motivering wat mense in die Bybel gehoorsaam laat reageer op God se uitstuuropdrag. Volgens hom is die Bybel 'n getuienis van God se sending; dus bied sending ' $n$ vaste punt wat die Skrif saambind (bl. 5-6). God se sending begin met die roeping van Abraham en bereik sy hoogtepunt met die koms van Christus (bl. 7). Hoewel Flemming toegee dat hierdie benadering nie alles in die Bybel kan verklaar nie en dat ander benaderings tot die Bybel nie uitgesluit kan word nie, is die Bybel 'n onontbeerlike instrument in God se sending (bl. 8).

In sy boek The mission of God: Unlocking the Bible's grand narrative gebruik Wright (2007) 'n missionale hermeneutiek as uitgangspunt om die groot verhaal van die Bybel te lees as 'n verhaal van God se sending na die wêreld. In God se sending gebruik Hy mense (Israel en die kerk) om die hele wêreld te bereik. Wright meen dat die Bybel in die geheel en elke deel daarvan in die lig van vyf belangrike momente gelees moet word (bl. 67-68):

- God se doel met die hele skepping wat die verlossing van die mens en die skepping van 'n nuwe hemel en aarde insluit;

- God se doel met die mens op aarde;

- die historiese verkiesing van Israel met onder andere aandag aan hulle taak ten opsigte van die nasies;
- die sentrale plek van Jesus van Nasaret, sy kruisdood en opstanding; en

- die roeping van die kerk om die agent van God te wees om sy seën na al die nasies uit te dra.

In hierdie benadering van Wright word die Bybel nie bloot as 'n getuienis van God se werksaamhede gesien nie, maar word die openbaringskarakter van die Skrif ook erken. Verder beklemtoon Wright 'n openbaringshistoriese benadering tot die Bybel.

Die idee van ' $\mathrm{n}$ missionale hermeneutiek sluit nou aan by die gedagte van 'n missionale kerk. In 'n artikel 'Missional church: A historical and theological analysis of an ecclesiological tradition' bied Nikolajsen (2013:249) 'n goeie oorsig van die ontwikkeling van hierdie begrip met besondere aandag aan die bydrae van Lesslie Newbigin en sy navolgers.

Tennent (2010:55) wys daarop dat daar in Willingen 'n sendingmodel voorgestel is waarin God se verlossende werk in die wêreld die kerk se taak voorafgaan. Bosch (1996:370), in aansluiting by Newbigin, vat die konsensus wat by Willingen bereik is, in drie punte saam:

- Die kerk is sending, sodat 'n mens kerk en sending nie kan skei nie.

- Die tuisbasis van sending is oral wat beteken dat elke kerkgemeenskap daaraan moet deelneem.

- Sending moet in 'n vennootskap onderneem word, maar sonder dat enige kerk toesighoudende gesag oor ' $n$ ander uitoefen.

Bauckham (2003) se werk Bible and mission: Christian witness in a postmodern world is 'n goeie voorbeeld van ' $n$ werk waarin daar vanuit 'n missiologiese perspektief na die Bybel in die geheel gekyk word. Hiervoor is twee vertrekpunte belangrik, naamlik dat die Bybel kanonies-hermeneuties, dit wil sê, in die geheel as 'n eenheid en vanuit 'n narratologiese perspektief gelees moet word. Die Bybel in sy geheel vertel 'n verhaal (bl. 11-12). In sy lees van die Bybel ondersoek Bauckham een aspek in die besonder, naamlik die beweging van die partikuliere na die universele (bl. 12). God identifiseer Homself as die God van Abraham, Israel en Jesus met die doel om Hom as die God van alle mense en die Here van alle dinge bekend te maak. In hierdie beweging van die partikuliere na die universele onderskei Bauckham drie dimensies, naamlik die temporele, die ruimtelike en die sosiale. Die temporele beweeg van die skepping na die eskatologiese toekoms. Die ruimtelike dimensie beweeg van Jerusalem na die eindes van die aarde. Die sosiale beweeg van een persoon na baie persone: van Abraham na die nasies, van Jesus na alle skepsels in die hemel, op die aarde en onder die aarde (bl. 12-15).

Dat die Ou Testament dus aandag behoort te kry in die bestudering van sending in die Bybel, is 'n onomwonde feit. Dit gebeur egter nie altyd nie. Die Nuwe Testament word baie meer beklemtoon wat te verwagte is, maar daar moet ' $n$ balans gehandhaaf word. In sy artikel 'The biblical narrative 
of the missio Dei: Analysis of the interpretive framework of David Bosch's missional hermeneutic' beskou Bekele (2011:155) dit byvoorbeeld as 'n leemte dat daar in Bosch se belangrike werk oor sending 'n gebrek aan 'n missiologiese lees van die $\mathrm{Ou}$ Testament is.

Aan die ander kant het Bekele (2011:153) waardering vir Bosch se uitgangspunt dat die Nuwe Testament as 'n missionêre dokument gelees moet word. Hy wys op Bosch se opinie (bl. 154) dat die teologie geen ander bestaansreg het as om die missio Dei krities te begelei nie. Hieruit is dit duidelik dat teologie en missiologie mekaar nodig het. Die Bybelwetenskappe moet help dat die missioloog nie sy vooronderstellings in die teks inlees nie, terwyl die missiologie moet keer dat die teologie nie maar net met die antieke teks besig bly nie.

Daar bestaan dus ongetwyfeld 'n wisselwerking tussen teologie in die algemeen en missiologie in die besonder. In hierdie wisselwerking moet die bestudering van die Bybel die Ou sowel as Nuwe Testament - 'n regmatige plek inneem. Tennent (2010:65) pleit dat die opleiding van sendelinge binne 'n trinitariese en ekklesiologiese raamwerk moet plaasvind, sodat alles verband hou met God (missio Dei) en sy kerk (missio ecclesiae). In die volgende afdeling word gelet op hoe die $\mathrm{Ou}$ Testament deur geleerdes vanuit so 'n missiologiese uitgangspunt benader word.

\section{Enkele beskouings van die $\mathrm{Ou}$ Testament en die missio Dei}

Omdat sending so opvallend in die Nuwe Testament voorkom, is daar baie missiologiese studies wat op die Nuwe Testament toegespits is. Soos blyk uit Bekele (2011) se beoordeling van Bosch, word navorsing oor sending dikwels onderneem met die gedagte, soms versluier en soms openlik, dat die Ou Testament nie so belangrik vir die missio Dei is nie. Die motivering hiervoor is dat die Nuwe Testament baie sterker missionêr gerig is as die Ou Testament.

Bosch (1996) spits hom toe op die Nuwe Testament in sy missiologiese bespreking van die Bybel. Hy is oortuig dat daar in die $\mathrm{Ou}$ Testament geen sprake daarvan is dat die gelowiges van die ou verbond gestuur is om mense buite hulle grondgebied tot die geloof oor te haal nie (bl. 17). Tog meen hy dat die Ou Testament baie belangrik is om sending in die Nuwe Testament te verstaan. Hy sonder veral drie sake in die $\mathrm{Ou}$ Testament uit wat in hierdie opsig betekenisvol is (bl. 17-19):

- Daar was 'n duidelike verskil tussen die geloof van Israel en die omringende volke. Laasgenoemde was vasgevang in die seisoensiklus, maar Israel het die geskiedenis gesien as die terrein waarop God werk.

- God het ook aan sy mense beloftes gegee. Hierin het God Hom aan die mense van die Ou-Testamentiese tyd verbind om namens hulle in die toekoms op te tree.

- God het Israel uitgekies; tog word dit algaande duideliker dat God ook 'n oog vir die nasies het. Hy is die God van Israel, maar ook die God van die hele wêreld.
In die res van hierdie afdeling word besin oor die gebruik van die $\mathrm{Ou}$ Testament in die interpretasie van die begrip missio Dei. Dit is uiteraard onmoontlik om die bestudering van die sendingsgedagte in die $\mathrm{Ou}$ Testament omvattend te bespreek. Die klem val op 'n aantal voorbeelde uit verskillende benaderings en standpunte in onlangse literatuur sonder om te probeer om alles te bespreek wat oor die onderwerp gepubliseer is.

Dit is inderdaad waar dat die Ou Testament soms gebruik word op 'n manier wat nie daaraan reg laat geskied nie. Dit gebeur veral wanneer dit eksemplaries gebruik word, byvoorbeeld wanneer daar persone, gebeure, situasies of uitsprake in die Ou Testament gesoek word wat parallelle met hedendaagse persone, gebeure, situasies of uitsprake toon en afleidings vir vandag dan direk uit die parallelle gemaak word - ook wat sending betref.

'n Voorbeeld van die eksemplariese gebruik van die $\mathrm{Ou}$ Testament is 'n studie van Carrol Rodas (2013), naamlik 'Biblical perspectives on migration and mission: Contributions from the Old Testament'. Hierin let die outeur veral op twee temas, naamlik Abraham en Josef as migrante en die Ou-Testamentiese wette oor vreemdelinge (bl. 12). Wat Abraham en sy nageslag betref, vra hy hoe hulle aan hulle roeping voldoen om God se seën na die wêreld te bring. Die wette oor die vreemdelinge sien hy as morele rigtingwysers vir vandag (bl. 12). Nadat hy Abraham se lewe kortliks opgesom het (bl. 12-13), gebruik hy die aartsvader se optrede in Egipte (hy het Sarai oorgehaal om te sê sy is sy suster) om 'n oplossing te vind vir die huidige probleem van migrasie (bl. 13). Abraham het volgens hom die keuse gehad om óf 'n leuen te vertel wat hom in staat sou stel om die grens na Egipte oor te steek óf om sy mense aan hongersnood bloot te stel. Carrol Rodas wil Abraham nie verontskuldig nie, maar verduidelik sy taktiek ook met die oog op die vergesogte dinge wat migrante moontlik moet oorweeg om hulle lewens te red of te verbeter (bl. 18). Hierna bespreek Carrol Rodas die verband tussen die Ou-Testamentiese wette en die missio Dei (p. 18) en gee besondere aandag aan die wette oor vreemdelinge (bl. 20). Die Ou Testament was uniek in daardie tyd ten opsigte van die omvangryke beskerming van vreemdelinge (bl. 20-21). Die outeur sê daar was twee redes daarvoor, naamlik dat die volk self vreemdelinge in Egipte was en dat God vreemdelinge liefhet (bl. 21). Hy beklemtoon dat dit geensins eenvoudig vir ' $n$ vreemdeling is om deel van 'n nuwe samelewing te word nie (bl. 22). Hierdie wette moet volgens hom ook vandag toegepas word. 'n Voorbeeld is dat die kerk gasvryheid moet bewys aan emigrante in sy midde (bl. 23). Die manier waarop die Ou Testament in hierdie studie gebruik word, illustreer die eksemplariese gebruik van die $\mathrm{Ou}$ Testament.

In die artikel 'Missio Dei in the book of Job' gaan Waters (2009:99) van die standpunt uit dat Job missionaal is in die sin dat wanneer gelowiges onverdiend ly, hulle vir ongelowiges getuies van God se goedheid, regverdigheid, genade en liefde is. Job is die eerste voorbeeld van 'n individu wat deur 
God gebruik word om sy sending na die wêreld te demonstreer (bl. 20). Die missio Dei begin by Job met lyding. Wat merkwaardig is, is dat God die inisiatief neem en dat dit daarop uitloop dat sy volgeling aan 'n geveg met die aanklaer blootgestel word (bl. 23). Job se lyding is fisies, sosiaal, emosioneel en geestelik (bl. 24). Volgens Waters het die skrywer van die boek Job twee doelstellings gehad, naamlik om 'n regstelling vir die verkeerde leer oor vergelding te bied (soos by Job se vriende), en 'n kind van God se gebruik van ervaring om 'n invloed op wêreld te hê (bl. 32). Waters gebruik ook ander persone soos Abel en Noag as voorbeelde van lyding (bl. 29). Uit hierdie gegewens mak Waters 'n eksemplariese toepassing op die gelowiges van vandag.

Sekere gedeeltes in die Ou Testament kry dikwels aandag wanneer daar oor sending gepraat word. Jesaja is besonder gewild veral die knegliedere in die tweede deel daarvan. 'n Goeie voorbeeld hiervan is die artikel " A light to the nations" (Isaiah 42:6 and 49:6): Inter-textuality and mission theology in the early church' van Bird (2006). Hy dui aan hoe die sendingywer van die vroeë kerk deur sekere verse in Jesaja (veral 42:6 en 49:6) geïnspireer is (bl. 123). Een van sy gevolgtrekkings is problematies, naamlik die stelling dat die huidige Christene moet probeer om die Ou Testament te lees soos wat die Christene van die eerste eeu dit gedoen het, naamlik binne 'n Christologiese, 'n heilshistoriese en 'n missiologiese raamwerk: Christologies is Christus die kneg waarvan Jesaja gepraat het; heilshistories het die lyn wat deur die $\mathrm{Ou}$ Testament loop, naamlik die doel van die skepping om God te verheerlik, in die kerk sy volle ontplooiing gekry; en missiologies het die vroeë kerk in die $\mathrm{Ou}$ Testament genoeg getuienis gesien van God se aandag aan die mense buite die grense van Israel (bl. 131). Die probleem met hierdie benadering is dat dele van die $\mathrm{Ou}$ Testament soms alleen vanuit die Nuwe Testament gelees word, sonder om die eie aard van die Ou Testament altyd in ag te neem.

'n Meer verantwoorde hantering van tekste uit Jesaja word in Evans (2011) se bydrae 'A light to the nations: Isaiah and mission in Luke' aangetref. Hy toon aan hoe Lukas in sy evangelie en in Handelinge by belangrike gedeeltes uit Jesaja aansluit 49:6 wat duidelik sê dat God se lig vir die nasies na alle volke toe moet gaan (bl. 105). Jesaja was vir Lukas se verstaan van die kerk se sendingsopdrag absoluut grondliggend (bl. 93). Dit is belangrik dat Evans in sy bespreking van Jesaja nie die Nuwe-Testamentiese perspektief in Jesaja inlees nie, maar aantoon hoe Lukas by Jesaja aansluit en dit herinterpreteer in die lig van die werk van Jesus Christus:

- Die roeping van Abraham en die tweede gedeelte van Jesaja is gedeeltes uit die Skrif wat dikwels in besinning oor sending betrek word, maar ewe dikwels met te min aandag aan ander belangrike gedeeltes van die $\mathrm{Ou}$ Testament. Tennent (2010) is 'n voorbeeld van 'n teoloog wat in sy bybelse begronding van sending baie aandag aan die $\mathrm{Ou}$ Testament gee, maar meestal op Abraham en die tweede gedeelte van Jesaja konsentreer. Die beloftes wat God aan Abraham gegee het, is vir hom baie belangrik, veral omdat al die geslagte en nasies van die aarde in Abraham geseën sou word. God beloof nie net om Abraham en die volk Israel te seën nie, maar dat die seën op grond van Abraham se gehoorsaamheid ook sal uitgaan na al die nasies van die wêreld. Die seën is dus bedoel vir Abraham, vir sy nageslag en vir al die nasies van die wêreld (bl. 108). Uit die verbond met Abraham lei Tennent drie belangrike temas af (bl. 110-114): God is die bron en die inisieerder van die sending:

- Die verbond met Abraham maak dit duidelik dat God 'n sendende God is.

- Die verbond met Abraham openbaar dat God vir al die nasies omgee.

Die Bybel is die verhaal van God se verlossende, historiese inisiatief ter wille van sy skepping. Sending spruit hieruit voort.

Vervolgens gee Tennent (2010:116-121) aandag aan Jesaja se knegliedere, waarin hy veral vier temas onderskei (bl. 117):

- Die kneg word op 'n sending deur die Here gestuur.

- Die sending gaan gepaard met plaasvervangende lyding.

- Alhoewel die kneg gaan ly en verwerp sal word, sal hy verhoog word en in die gelyk gestel word.

- Sy lyding sal geregtigheid, redding en seën vir al die nasies bring.

Uit hierdie bepreking maak Tennent (2010:119) drie belangrike gevolgtrekkings oor die missio Dei: Die Vader neem die inisiatief; die sending is globaal en nie net vir Israel bedoel nie; en deur die sending kom daar geregtigheid, redding en seën vir alle nasies. In sy werk verwys Tennent talle kere na Genesis, Eksodus, Jesaja en Psalms, maar aan die res van die Ou Testament gee hy weinig aandag.

Natuurlik kan daar op gemotiveerde maniere na die saak van die missio Dei in die Ou Testament gekyk word. Een manier is om 'n tersaaklike tema in die Ou Testament in sy geheel of in 'n deel daarvan te bestudeer. Die ander manier is om op 'n besondere boek te konsentreer.

'n Goeie voorbeeld van die eerste benadering is die werk van Ott et al. (2010). Die outeurs is verantwoordelik vir 'n hele afdeling oor die Ou Testament in die deel van 'n boek wat oor die bybelse grondslag vir sending handel (bl. 3-24). Hulle doel is nie om die Ou Testament in sy geheel te behandel nie, maar hulle wil die klem op God en die nasies in die $\mathrm{Ou}$ Testament laat val. So 'n benadering verskraal nie die teologie van die Ou Testament tot ' $n$ sendingsteologie nie, maar belig 'n belangrike tema - later in die boek gee hulle ook aan ander temas aandag. Hulle bied 'n oorsig van hoe die tema van God en die nasies deur die Ou Testament loop. Hulle begin met die skepping en die sondeval (bl. 3). Daarna bespreek hulle die oorsprong van die nasies (bl. 4-5) en die ontstaan van Israel as 'n koninkryk van mense (bl. 6-7). In die verdere bespreking (bl. 7-21) gee hulle aandag aan die aartsvaders, die wet, die psalms, dat God waardig is om deur die nasies 
geprys te word, die profete en 'n eskatologiese hoop vir die nasies. Vervolgens ondersoek hulle die vraag of Israel na die nasies gestuur is (bl. 21-23) en onderskei tussen sentrifugale en sentripetale sending. Hulle gevolgtrekking is dat daar nie werklik sprake van sentrifugale sending in die Ou Testament is nie (bl. 23). Daarna bespreek hulle die tema van God en die nasies in die Nuwe Testament (bl. 25-54). Hierdie bydrae verteenwoordig 'n goed gebalanseerde siening. Nie alles in die Ou Testament is sending nie. Hulle let ook deeglik op die geskiedenis.

Daar is ' $n$ beter balans in hierdie artikel as byvoorbeeld in die benadering van Bennema (2011:257) wat in sy artikel 'Spirit and mission in the Bible: Toward a dialogue between biblical studies and missiology' sê dat Bybelwetenskaplikes moet aanvaar dat die hele Bybel missionaal is. Hy het ook 'n tematiese benadering wanneer hy die verhouding tussen die Heilige Gees en sending bespreek. Wat die Ou Testament betref, wys Genesis 1-3 dat God gemeenskap met die mens wil hê en dat die Gees deel van die gemeenskap is; dat die sondeval die kommunikasie tussen God en die mens skade berokken het; dat God die gemeenskap met die mens nie weens die sondeval laat vaar het nie; dat die Gees onontbeerlik in hierdie gemeenskap is; dat die Gees die lewe van alle skepsels skep en onderhou; en dat Hy God se mense in die toekoms sal hernu en hervorm. Die Gees waarborg dus God se voortgesette gemeenskap met die mens. Israel moes die nasies deur hulle optrede nader trek, maar het daarin gefaal. God het egter sy doel bereik deur die Messias wat Hy gestuur het. Vir Bennema lê die grootste verskil tussen die Ou en die Nuwe Testament daarin dat sending in die Ou Testament sentripetaal is, terwyl dit sentrifugaal in die Nuwe Testament word (bl. 240-242). Alhoewel hy die Ou Testament feitlik net uit die perspektief van sending wil lees, is sy tematiese benadering wel gebalanseerd en trek hy die lyn van die $\mathrm{Ou}$ Testament deur na die Nuwe Testament.

Hogg (1988) het Psalm 22 in 'n artikel 'Psalm 22 and Christian mission: A reflection' geïnterpreteer met die oog op Christelike sending. Sy studie is ' $n$ goeie voorbeeld van hoe 'n spesifieke gedeelte van die Ou Testament op 'n verantwoorde manier bestudeer kan word met die oog op ' $n$ boodskap vir sending. Hy begin met 'n indringende eksegese van die psalm (bl. 238-241) waarin hy aandag gee aan die vyf boeke van Psalms, Mowinckel en Gunkel se bydrae en die struktuur van Psalm 22 as 'n klaaglied. Wanneer daar na die psalm vanuit die standpunt van 'n Christen gekyk word, wys dit vooruit na Jesus. Wat die verhouding tussen die psalm, die Nuwe Testament en sending betref, noem Hogg (bl. 241242) 'n aantal fundamentele sake:

- God is die Skepper, maar Hy werk ook in die geskiedenis.

- God het Israel tussen die nasies geplaas met 'n universele doel soos blyk uit Eksodus 19:5-6.

- Israel erken God as die Skepper van alle volke en dat Hy soewerein oor hulle is.

- Die nasies kon deel kry aan die heil met Israel as die lig vir die nasies. Die volke sou na Sion kom, wat dus neerkom op sentripetale sending.
- Christene vergeet te maklik dat die psalms met die mens se bestaan en dood in die Ou-Testamentiese konteks te doen het.

Die lyding van die psalmis is 'n simbool van die verbondsgemeenskap (Hogg 1998:242) wat ook van hoop spreek. Volgens hom sê die psalms niks spesifieks oor sending en hoe die bekering van die nasies bereik gaan word nie, maar dit is wel van toepassing op die situasie van vandag. Te midde van die baie ellende en twis, ook onder gelowiges, word dikwels gevra waar God is (bl. 245). In die getuienis van die kerk word gebid vir lyding, nederigheid, wysheid en onderskeiding in die kerk se rol as dienskneg in die sending (bl. 246). In sy bestudering van Psalm 22 begin Hogg nie met sending nie, maar hy kom wel by 'n boodskap uit vir die kerk in sy sendingwerk vandag.

Boda (2011) se studie " Declare his glory among the nations": The psalter as missional collection' is ' $\mathrm{n}$ baie goeie voorbeeld van 'n verantwoorde tematiese benadering tot 'n spesifieke boek in die Ou Testament. Boda het die tema van die nasies op twee maniere in die boek Psalms ondersoek. Eerstens het hy die tema in die boek in sy geheel nagevors; daarna het hy gelet op hoe die nasies in die lineêre konteks van die boek, dit wil se die ordening en rangskikking van die psalms, na vore kom (bl. 14). Wat die tema deur die hele boek betref, verbind hy die nasies aan die heerskappy van die Here in die wêreld. Omdat die Here oor die hele wêreld regeer, regeer Hy ook oor die nasies (bl. 14-16). Die nasies sal uiteindelik na Sion kom om die Here se heerskappy te erken (bl. 19). Israel het die taak gehad om God onder die nasies te loof (bl. 21), maar die nasies sal uiteindelik ook deelneem aan die lof van die Here (bl. 22-23). God het die nasies egter ook as instrumente gebruik om Israel te straf (bl. 25-26). Deur hulle optrede moes Israel die lof van die Here onder die nasies uitbrei; sodoende word hulle sending na die nasies 'n werklikheid (bl. 26-27).

Boda (2011) gee ook aandag aan die plek van die nasies in die struktuur van die psalms as bundel. In hierdie opsig sluit hy aan by 'n onlangse tendens om die struktuur van die bundel ernstig op te neem. Hierin speel die doksologieë wat telkens aan die einde van die eerste vier boeke van die psalms voorkom 'n besondere rol (bl. 30-31). Hierdie lofprysings, veral in Psalm 72:19 en 145:21, wys vooruit na 'n tyd wanneer ook die nasies die Here sal loof. Boda vestig verder die aandag op die psalms wat by belangrike oorgange in die boek voorkom. In hierdie psalms sien hy 'n voortgang van die Here na die koning, dan na die volk van God en dan na die nasies (bl. 36). Hieruit word dit vir hom duidelik dat Israel moes besef dat hulle nie maar ter wille van hulleself bestaan het nie, maar dat hulle ook 'n taak ten opsigte van die nasies gehad het (bl. 37). Hy is versigtig om nie van individuele tekste wat na die taak van die kerk vandag verwys te spring nie, maar probeer aantoon dat hierdie belangrike tema in die psalms ook na die Nuwe Testament en die werk van Christus deurgetrek kan word (bl. 38-39).

Blackburn (2012) bestudeer Eksodus vanuit 'n missiologiese perspektief in The God who makes himself known: The missionary 
heart of the book of Exodus. Dit is 'n omvattende werk en 'n goeie voorbeeld van ' $n$ indringende studie van 'n spesifieke boek uit 'n missiologiese perspektief. Die outeur gee aandag aan die boek in sy geheel. Hy meen dat die Here se missiologiese doel, naamlik om Hom aan die nasies bekend te maak, die teologiese spilpunt van die boek is (bl. 15). Hy is van mening dat die Ou Testament nie genoeg aandag kry in hierdie verband nie. Hy sê daar word baie op die Nuwe Testament gefokus, maar wat die Ou Testament betref, word daar dikwels net 'n paar tekste uitgesonder, soos Genesis 12:1-3, Eksodus 19:4-6 en Jona. Volgens hom is die probleem dat die Ou Testament met die lens van die Nuwe Testament gelees word. Dit geld veral die sendingopdrag in Matteus 21:18-20. Hy meen dat ons sending in die Nuwe Testament nie sonder die $\mathrm{Ou}$-Testamentiese agtergrond kan verstaan nie (bl. 16). Met hierdie uitgangspunt word daar na tekste gekyk wat eksplisiet na die nasies verwys om ons verstaan van sending uit te brei. In aansluiting by Bauckham (2003) is Blackburn (2012:17) verder van mening dat die beweging van die partikuliere na die universele in Eksodus baie belangrik is, want Israel se bestaan het 'n universele doel gehad. Blackburn wil 'n kanonieke benadering volg en wys in die verband op vyf belangrike sake, naamlik die finale vorm van die verskillende boeke, die teologiese nadenke wat uitgaan van die kanonieke weergawe van die geskiedenis (afgesien van die beoordeling van die historisiteit van die boeke), die Bybel as teologiese normatief, die teologiese eenheid van die Bybel en die behoud van die stem van die Ou Testament, wat nie deur die Nuwe Testament verberg moet word nie (bl. 18-19). Vir hom staan God se sendingdoel sentraal in Eksodus. Hy ondersoek die verskillende dele van die boek in die lig van hierdie basiese uitgangspunt. Verder is die kanonieke konteks en die selfopenbaring van God baie belangrik. Dit is 'n baie goeie werk wat erns maak met die boodskap van die boek in sy konteks. Tog kan Bauckham se uitgangspunt daartoe lei dat daar soms gevolgtrekkings in die teks ingelees word wat nie duidelik daarin na vore kom nie. So sê hy byvoorbeeld dat Israel die grense van die tabernakel moes uitbrei om alle nasies in te sluit (bl. 150), 'n stelling wat nie in die teks voorkom nie.

Voorbeelde van werke wat op ' $n$ verantwoorde wyse sending in die hele $\mathrm{Ou}$ Testament ondersoek is Mission in the Old Testament: Israel as a light to the nations (Kaiser 2012) en die twee boeke The mission of God: Unlocking the Bible's grand narrative (Wright 2007) en The mission of God's people: A Biblical theology of the church's mission (Wright 2010). Die subtitel van Kaiser (2012) se werk, Israel as a Light to the Nations, sluit aan by Jesaja 49:6. Die outeur gaan ook uit van die gedagte van die missio Dei wat by God wat na die wêreld stuur begin en waarin die belofte aan Abraham in Genesis 12:3 'n sentrale plek inneem (bl. xviii-xix). Hy volg 'n tematiese benadering waarin sekere sake uitgesonder word, maar die boodskap van die Ou Testament as eenheid nie 'n plek kry nie. Hy fokus op die oergeskiedenis (Gen 1-11 - hfst. 1), die tyd van die aartsvaders en Moses (gedeeltes uit Gen en Eks - hfst. 2), die belofte aan Dawid (gedeeltes uit Jos en Sam - hfst. 3), Psalms (hfst. 4), enkele persone soos Melgisedek, Jetro, Ragab en
Naäman (hfst. 5), Israel as 'n lig vir die nasies (Jes - hfst. 6) en Jona en enkele ander profete (hfst. 7). In sy laaste hoofstuk dui hy aan hoe Paulus by die Ou-Testamentiese sendinggedagte aansluit. Hierdie werk met sy beperkte omvang bestaan uit 'n seleksie van belangrike gedeeltes wat in 'n groot mate verteenwoordigend is van die gedeeltes in die Ou Testament wat dikwels in die literatuur gebruik word om die sendinggedagte in die $\mathrm{Ou}$ Testament uit te werk. Wat opmerklik is, is dat die wysheidsliteratuur van die $\mathrm{Ou}$ Testament glad nie aan die orde kom nie.

Wright $(2007 ; 2010)$ het in albei sy boeke 'n groot bydrae gelewer tot die gedagte om die Bybel in die geheel vanuit 'n missionale perspektief te lees. Hy (Wright 2010:17) wys in sy boek The mission of God is what unifies the Bible from creation to new creation daarop dat al die groot dele van die kanon, al die groot episodes en al die groot leerstellinge met die Bybel se sentrale karakter verband hou, naamlik die lewende God en sy groot plan en doel vir die hele skepping. Hy beklemtoon ook die belangrikheid van die wisselwerking tussen missiologie en teologie (bl. 19-20). Oor die verhouding tussen die kerk en sending sê hy (Wright 2007):

It is not so much the case that God has a mission for his church in the world, as that God has a church for his mission in the world. Mission was not made for the church; the church was made for mission - God's mission. (bl. 62)

Hy (Wright 2007) benader die Bybel dus volgens 'n missionale hermeneutiek waarvan die uitgangspunt die volgende is:

... a missional hermeneutic proceeds from the assumption that the whole Bible renders to us the story of God's mission through God's people in their engagement with God's word for the sake of the whole of God's creation. (p. 48, [Wright se kursief])

Die outeur (Wright 2007:63-64; 2010:39) verdeel die verhaal van die Bybel in vier groot segmente, naamlik die skepping, die sondeval, die verlossing in die geskiedenis en die herskepping. Die grootste deel van die Bybel handel oor die verlossing in die derde fase.

In die bespreking hierna word op Wright se werk van 2010 gefokus. Die outeur is van mening dat ' $n$ mens die hele Bybel volgens 'n missionale hermeneutiek kan lees (bl. 46). Vir sy bespreking van die sendingtaak van die kerk het Wright tekste gekies wat veral belangrik is vir gelowiges se taak as deel van God se sending op aarde (bl. 47). Dit is interessant om sy keuse te ontleed om vas te stel of 'n betekenisvolle afleiding daaruit gemaak kan word. Uit die indeks van Skrifgedeeltes waarna hy verwys (bl. 289-296), kan 'n beeld gevorm word van die seleksiepatroon. In die Ou Testament verwys hy dikwels na Genesis, Eksodus, Deuteronomium, Psalms, Jesaja en Jeremia. Ongeveer $75 \%$ van sy verwysings na die $\mathrm{Ou}$ Testament is na hierdie ses boeke. Afgesien van verwysings na Genesis en Eksodus, verwys Wright selde na ander historiese gedeeltes in die $\mathrm{Ou}$ Testament. Daar is byvoorbeeld geen verwysings na Kronieke, Esra en Ester nie. Die outeur verwys ook nie na Job, Hooglied en Prediker nie. Wat die groot profete betref, is daar teenoor die talle verwysings na Jesaja en Jeremia net tien na Esegiël. 
'n Ernstige beswaar teen Wright is dat groot dele van die $\mathrm{Ou}$ Testament óf geïgnoreer word óf bloot oppervlakkig as bewysmateriaal gebruik word.

Die studie van Martens (2006) oor Jesaja, naamlik 'Impulses to global mission in Isaiah', illustreer hoe 'n boek in die $\mathrm{Ou}$ Testament bestudeer kan word met die oog op 'n boodskap vir sending. Hy gaan binne die raamwerk van die missio Dei van die beginsel uit dat God van die begin af 'n missionale doel gehad het. Van die begin af het God 'n gemeenskap van mense in die oog gehad. Dit sou Israel insluit, maar nie tot Israel beperk wees nie (bl. 59). Hiervoor is Jesaja in die $\mathrm{Ou}$ Testament baie belangrik. Martens beroep hom op Jesaja 45:22, wat praat van die verlossing tot by die verste uithoeke van die wêreld. Sy doel is om 'n omvattende denkraamwerk voor te stel waarbinne tekste soos hierdie gelees kan word. Die eerste deel van Jesaja is veral op Israel se sonde gerig, alhoewel dit duidelik is dat die profeet bewus was van die groter wêreld daarbuite. In Jesaja 40 en verder word dit duidelik dat God se plan verder reik. Martens maak 'n paar fundamentele opmerkings waarin hy die boodskap van Jesaja 40 en verder duidelik na vore laat kom (bl. 60-62):

- God is soewerein oor al die nasies.

- God is die enigste God.

- God is 'n God van nuwe dinge, soos 'n nuwe eksodus uit Babel en 'n nuwe verbond met Dawid.

- God is 'n verlosser. Sy verlossende aktiwiteite gaan verder as Israel - na die nasies.

God se globale sending berus op hierdie vier pilare volgens Martens (bl. 63). God het ook 'n oog vir die nasies. Wat God se sending betref, is daar twee sake wat Martens uitsonder. Eerstens is die nasies getuies van wat God aan Israel doen. Deur sy bestaan is Israel ' $n$ lig vir die nasies (v. 6 in Jes 42:1-9 en v. 6 in 49:1-13). Wat die beeld van die lig betref, trek Martens 'n lyn na die Nuwe Testament met Christus as die lig vir die wêreld. Dit is waar dat die nasies na Israel toe kom in Jesaja (bl. 63-65). In die tweede plek is daar sprake van getuienis in die woorde deur te gaan na die nasies of te praat met die nasies. Martens wil sending in die Ou en Nuwe Testament nie bloot as sentripetaal en sentrifugaal kategoriseer nie. Albei soorte sending kom in die Ou sowel as die Nuwe Testament voor. So is Jesaja 42:1-4 wat oor die kneg wat ook buite Israel geregtigheid bring, handel, en Jesaja 66:19 wat oor die oorblyfsel wat na die nasies moet gaan, handel, werklik sentrifugaal. Die kerk het die taak om die boodskap ook na hulle bure uit te dra (bl. 66-68). Wat baie waardevol in hierdie bydrae is, is dat Martens erns maak met die boodskap van die boek self, al kies hy sake wat veral met sending verband hou. Aan die ander kant beteken sy keuse dat sekere sake in die boek soos dat daar ook 'n oordeel oor die nasies uitgespreek word, nie baie aandag kry nie.

Hierdie bespreking maak dit duidelik dat daar in die gebruik van die Ou Testament met die oog op sending gevalle is wat eksemplaries en oppervlakkig te werk gaan, maar dat daar ook gevalle is wat op 'n meer verantwoorde manier met gedeeltes uit die $\mathrm{Ou}$ Testament omgaan. Laasgenoemde kom veral voor waar die boodskap van die gedeelte in die oorspronklike konteks ernstig opgeneem word en daar nie maar van die $\mathrm{Ou}$ Testament na vandag gespring word nie.

\section{Akademiese opleiding, studie van die Ou Testament en missio Dei}

Dit is belangrik om te vra wat die verhouding tussen missiologie en die ander teologiese dissiplines behoort te wees - ook met die oog op die opleiding van predikante. Bosch (1996) bied 'n goeie oorsig van die ontstaan van missiologie as 'n wetenskap. Hy wys daarop dat die teologie ná die Verligting in vier onderafdelings ontwikkel het, naamlik die Bybelwetenskappe, kerkgeskiedenis, sistematiese teologie en praktiese teologie. Hierdie benadering is ook toegepas op die opleiding van inheemse predikante. Toe die behoefte aan opleiding in missiologie ontstaan het, was dit eerstens logies om dit aan een van die vier bestaande areas te verbind. Gewoonlik was praktiese teologie die logiese keuse (bl. 490). 'n Alternatiewe benadering was om missiologie as 'n selfstandige wetenskap te sien wat daartoe gelei het dat dit dikwels as 'n aanhangsel van teologie beskou is (bl. 492-493). In missiologie het die tendens voorgekom om die vierdeling van teologie te volg met die grondslag (soos Bybelwetenskappe), teorie (soos sistematiese teologie), sendinggeskiedenis en die praktyk van sendingwerk as onderafdelings (bl. 492). 'n Derde benadering was om missiologie glad nie as ' $n$ aparte dissipline te hanteer nie, maar om van al die teologiese dissiplines te verwag om die sendingdimensie in hulle werk in te sluit. Hierdie benadering (wat Bosch self sou verkies) is egter dikwels gebrekkig toegepas omdat alle teoloë nie die nodige kennis en insig het om dit in hulle werk in te sluit nie (bl. 492).

Bosch (1996:493) wys daarop dat as sending as deel van die wese van die kerk gesien word, moet die teologie ook in die sendingsituasie geanker wees. Die teologie kan net teologie wees as dit missionaal is (bl. 494). Bosch voel dus sterk dat die derde benadering wat hierbo genoem is die beste is, naamlik dat die idee van sending deur alle dissiplines moet loop (bl. 494). Hy verkies om missiologie as 'n aparte vak te behou al is dit net weens praktiese redes, maar dan moet missiologie in wisselwerking met die ander dissiplines tree,'n gespreksgenoot daarvan wees (bl. 495). Missiologie het dus die taak om die ander dissiplines ook van die sendingtaak bewus te maak wat daartoe sal bydra dat die teologie nie stagneer nie (bl. 496).

Tennent (2010:60) beklemtoon die missionale karakter van alle teologiese dissiplines. Vir hom is teologie fundamenteel missionaal, omdat die bybelse teologie God as 'n missionêre God openbaar. Hy wil teologie nie bloot gebruik om tekste te identifiseer wat sending onderskryf nie. Hy waarsku teen die gebruik van die bewysteksmetode (bl. 61). Hierin sluit hy aan by Wright (2007:51) se siening dat die hele Bybel die verhaal vertel van God se sending deur sy mense ter wille van alle mense op aarde.

In hierdie verband oordeel Strauss et al. (2010:xiii) dat dit deel van die taak van 'n sendingteologie is om ' $n$ duidelike 
bybelse taakaanduiding vir sending uit te werk sowel as om die missionêre aspek van die evangelie aan die kerk en akademie voor te hou. Dit kan maklik gebeur dat die kerk en die akademie veral op daardie sake konsentreer wat vir hulle binnewerking belangrik is (bl. xiv). 'n Missionale teologie moet die missionale dimensie van die verskillende teologiese dissiplines aandui (bl. xviii). In 'n sekere sin is alle teologie missionale teologie omdat dit te doen het met God se missionale doel met die wêreld. Tog het die missionale teologie die ander teologiese dissiplines nodig, omdat missiologie sonder die ander teologiese dissiplines gevaarlik en spekulatief kan word (bl. xix). Dit is dus belangrik om 'n noue band tussen missiologie en die ander dissiplines te sien waar ' $n$ bybelse teologie van sending ' $n$ brug tussen missiologie en die ander dissiplines kan bou. 'n Bybelse teologie (dus 'n dissipline soos openbaringsgeskiedenis) ondersoek die ontwikkeling van temas in die kanon en tersaaklike bydraes van skrywers en boeke. 'n Bybelse teologie van sending ondersoek die ontwikkeling van die sendingtema in die Bybel (bl. xx).

Cerny (2010) bied 'n bruikbare oorsig van die verhouding tussen teologie in die algemeen en missiologie in die besonder in 'The relationship between theology and missiology: The missiological hermeneutics'. Hy is oortuig daarvan dat elke teologiese dissipline ' $n$ missiologiese dimensie in hulle werk moet insluit. Vir hom is die Bybel 'n boek van sendelinge. Dit handel oor God se sending, is deur sendelinge geskryf en die Bybel se doel is die voortgaande sending van God en die kerk (bl. 106). Sending is nie maar 'n aktiwiteit van die kerk nie; dit is die uitdrukking van die bestaan van die kerk (bl. 107).

Die Sinode van die Gereformeerde Kerke in Suid-Afrika (GKSA) het in 2006 'n besluit hieroor geneem. Onder die opskrif 'Missiologiese gerigtheid' is aangedui dat 'alle aspekte van die teologiese kurrikulum 'n meer missionêre fokus' moet kry - die teologie moet missionêr ingestel wees (GKSA 2006:804). Die saak is vir verdere aandag na die Senaat van die Teologiese Skool verwys, maar daar is geen aanduiding van wat onder missionêre gerigtheid verstaan word en hoe dit in die kurrikulum na vore moet kom nie. Die Sinode van 2009 het meer lig hierop gewerp. In 'n rapport van die Kuratorium van die Teologiese Skool wat oor opleiding vir bediening in Afrika handel, word daarop gewys dat alle kerke 'n missionêre karakter het en dat missiologie eintlik 'n deeldissipline van alle teologiese dissiplines is (GKSA 2009:809).

In 2012 is 'n verslag van die Kuratorium oor die missionêre aard van die hele kurrikulum aan die Sinode voorgelê (GKSA 2012:476-477). Die besluite wat geneem is, toon egter geen noemenswaardige vordering nie. Daar word slegs na opleiding verwys wat op so 'n manier moet geskied dat predikante en kerke effektief sending kan doen in 'n gedeelte wat handel oor die geheel van die kerk se dienswerk in en aan die wêreld. Verder word dosente wat by die predikantsopleiding betrokke is, aangespoor om sover moontlik aan die missionêre gerigtheid aandag te gee in die aanbieding van hulle vakke (bl. 477). Daar is egter geen aanduiding dat daar sedert die besluit van 2006 enige aanpassing in die leerinhoud van kurrikula plaasgevind het nie. Op die tafel van die Sinode van 2015 kom daar in die verslag van die Kuratorium geen verwysing voor na die saak van die missiologiese toespitsing van opleiding nie. Die saak van die missio Dei kom wel aan die orde in die rapporte van die Deputate Omkeerstrategie (GKSA 2015:491-529). Hierin is daar ook ' $n$ bespreking van die begrip met sy uitgangspunt van God wat stuur en die kerk wat deel het aan hierdie sending (bl. 497). Daar word ook verwys na afleidings uit die Ou en Nuwe Testament hieroor (bl. 497-498), terwyl daar 'n bylaag is waarin daar meer aandag aan die saak gegee word (bl. 517-523). In die tweede rapport word opmerkings en aanbevelings gemaak oor die opleiding van predikante, wat die inhoud van die kurrikulum sowel as die wyse van aanbieding betref (bl. 528). Die sake word egter weer na die Senaat en Kuratorium verwys. Wat uit hierdie oorsig van besluite oor die missionêre gerigtheid van die opleiding van predikante aan die Teologiese Skool afgelei kan word, is dat daar weinig aandag gegee is aan wat die missio Dei behels en hoe dit in die kurrikulum na vore moet kom.

\section{Missio Dei in Esegiël}

In die lig van die voorafgaande bespreking word die missio Dei in die boek Esegiël bespreek met 'n aanduiding van hoe dit in 'n kurrikulum aan die orde sou kon kom. Twee studies wat aandag aan die missio Dei in Esegiël gegee, sal eers kortliks bespreek word.

Martens (1999:75) oordeel in sy artikel ‘Ezekiel's contribution to a biblical theology of mission' dat Esegiël 'n belangrike bydrae tot 'n sendingteologie kan lewer. In sy bespreking van die boek gee hy aandag aan twee sake, naamlik die sogenaamde erkenningsformule (julle/hulle sal weet dat Ek die Here is) en die heerlikheid van die Here. Die erkenningsformule wys daarop dat die Here se doel met sy optrede nie die terugkeer van Israel was nie, maar dat Hy deur Israel en deur alle mense aanbid sal word. Die doel van die historiese gebeure is dus erkenning en gehoorsaamheid (bl. 76). Hieruit lei Martens af dat God wel die nasies van die wêreld in die oog het. God se doel is dat die nasies Hom moet ken (bl. 77). Uit hierdie gegewens maak Martens afleidings oor die doel van sending vandag:

Christian mission aspires to participate in God's project of bringing people to a recognition of Yahweh, and beyond that to an acknowledgment of his authoritative supremacy, and ideally to the goal of rendering him worship and obeying him. (bl. 78)

God neem die inisiatief en die bereiking van die ideaal is ook die resultaat van God se optrede (bl. 80).

Die heerlikheid van die Here is vir Martens (1999) die sleutel vir die verstaan van die boek in die geheel (bl. 83). Dit dui daarop dat God oor die kosmos heers. God is nie maar een van die gode nie; Hy alleen is God en die enigste wat aanbid kan word. Dit geld vandag steeds teenoor die aansprake van ander godsdienste soos onder andere die Islam (bl. 84). 
Idestrom (2012) het ook die tema van die heerlikheid van die Here in 'The revelation of God's glory as a source of hope: Missio Dei' bestudeer. Sy spits haar toe op Esegiël, maar vooraf bestudeer sy eers die res van die Ou Testament. Dit is 'n goeie voorbeeld van ' $n$ tematiese benadering waarin eers aan die saak in die $\mathrm{Ou}$ Testament aandag gegee word voordat daar na vandag beweeg word. Vir die kerk van vandag bring dit 'n boodskap van hoop wat na die wêreld uitgedra moet word sodat mense na die lig van die evangelie - Christus getrek kan word.

In die lig van bostaande opmerkings kan die vraag gevra word hoe die saak van 'n missionêre strekking in 'n boek soos Esegiël aan die orde kom en hoe die saak in die onderrig van voornemende predikante hanteer kan word. Die missionêre boodskap van die Ou Testament, in die besonder as deel van die teologie van die Ou Testament (ook genoem die openbaringsgeskiedenis), kan op twee maniere hanteer word. Een manier is om dit as een van verskillende temas te hanteer. Ander temas is byvoorbeeld die verbond, God se koninkryk, Ou-Testamentiese etiek en soortgelyke temas. In so 'n tematiese hantering kan die missionêre lyn deur die $\mathrm{Ou}$ Testament gevolg word en kan die skepping, sondeval, die roeping van Abraham en God se plan met die nasies onder andere aandag kry. 'n Ander manier is om te let op die teologiese temas in 'n boek of 'n groep boeke om te vas te stel of die genoemde temas vir die missio Dei ter sake is. So ' $n$ benadering waar eers op die temas in 'n boek gelet word en waar die missionêre tema nie as die uitgangspunt geneem word nie, behoort te voorkom dat die boodskap van 'n boek, 'n groep boeke of die Ou Testament in die geheel verskraal word tot missiologies relevante temas.

Omdat daar hierbo reeds gewys is op die belangrikheid van die heerlikheid van die Here in Esegiël, word die tema nie weer apart bespreek nie. In 'n onlangse studie, 'Ezekiel, prophet of the glory of the Lord', het Van Rooy (2012) 'n aantal belangrike temas in die boek Esegiël geïdentifiseer. Sonder om elke tema hier in detail te bespreek, word kortliks gelet op die relevansie van daardie temas vir die missio Dei.

\section{'n Profetiese roeping (Van Rooy 2012:131-132)}

In die boeke van die profete speel die roeping van 'n profeet dikwels ' $n$ besondere rol, veral by die drie groot profete. Esegiël moes besef dat sy roeping van God kom en dat hy volgens sy opdraggewer moes optree. Wanneer Jesus optree, word dit ook telkens beklemtoon dat Hy deur die Vader gestuur is en dat Hy moes doen wat die Vader aan Hom opdra soos onder andere in Johannes 5:19-47. Wanneer die kerk hom vandag oor sy roeping as deel van die missio Dei verantwoord, moet die kerk besef dat dit nie oor homself gaan nie, maar dat hy ten volle in God se diens is om God se opdrag uit te voer.

\section{'n Afwesige God (Van Rooy 2012:133-134)}

Die ballinge in Babel het in die besonder hiermee geworstel. Die problematiek van God se afwesigheid word ook beklemtoon deur die gesig in Esegiël 8-11 waar die heerlikheid van die Here die tempel verlaat. Tog het die Here in die ballingskap aan Esegiël verskyn en so getoon dat Hy oral teenwoordig is. In die finale gesig (Eseg 40-48) keer die heerlikheid van die Here weer terug na die tempel. Die dieptepunt van God se afwesigheid is die oomblik toe Jesus aan die kruis uitgeroep het: 'My God, my God, waarom het U My verlaat?' Juis dit waarborg dat God se kinders nooit verlaat word nie. Dit is waarom die kerk geroep word om God se teenwoordigheid in die wêreld duidelik in sy optrede te toon, veral wanneer die Woord in woord en daad na ongelowiges uitgedra word.

\section{'n Teosentriese boodskap (Van Rooy 2012:135-137)}

Hierdie tema sluit aan by die bespreking van Martens se behandeling van die erkenningsformule. Die betekenis van die Drie-eenheid, die uniekheid van God en sy heerlikheid het geen verdere verduideliking nodig nie. Hierdie boodskap word verder beklemtoon deur die gebruik van vaste formules in die boodskap van Esegiël (bl. 144-147).

\section{Oordeel en herstel (Van Rooy 2012:137-140)}

Die tema sluit duidelik aan by die groot lyn deur die $\mathrm{Ou}$ Testament, naamlik dié van skepping, sondeval en herstel. Hierdie lyn loop uit op Christus deur wie die verlossing bewerkstellig is en hou so verband met die kernboodskap wat die missio Dei uitdra. Ander sake wat hierby aansluit is die boodskap van Esegiël oor bekering (bl. 140-142), persoonlike verantwoordelikheid (bl. 142-144) en die toekoms van die huis van Dawid (bl. 144). Juis in die Messias het die beloftes aan die huis van Dawid hulle vervulling bereik en is dit deel van die kernboodskap wat vandag uitgedra moet word.

\section{Konklusie}

Dit is duidelik dat dit uiters wenslik is dat die missionale roeping van die kerk in teologiese onderrig besondere klem moet ontvang. Dit geld ook vir die onderrig in die Ou-Testamentiese vakke. Daar moet egter teen twee verkeerde maniere van die gebruik van die Ou Testament gewaak word. Die eerste is om die bewysteksmetode te gebruik waardeur tekste buite verband gebruik word ter ondersteuning van die belangrikheid van die kerk se missionale roeping. Die tweede is om die Ou Testament uitsluitlik vanuit' $n$ missionale hermeneutiese hoek te benader waardeur groot dele van die boodskap van die Ou Testament verlore kan gaan. Uit die bespreking van voorbeelde hiervan het dit duidelik geword dat groot dele van die historiese boeke van die Ou Testament en bykans al die wysheidsboeke nie behoorlike aandag ontvang nie. Daar is wel twee maniere waarop die boodskap van die Ou Testament duidelik oorgedra kan word. Die eerste is ' $n$ tematiese benadering waarin die tema van sending naas 'n verskeidenheid van ander temas aan die orde kan kom. Die tweede is om die boodskap van 'n boek of groep boeke te bepaal en dan te oordeel op watter manier daardie boodskap van toepassing gemaak kan word op die missionêre roeping van die kerk vandag. 


\section{Erkenning \\ Mededingende belange}

Die outeur verklaar dat hy geen finansiële of persoonlike verbintenis het met enige party wat hom nadelig of voordelig kon beïnvloed het in die skryf van hierdie artikel nie.

\section{Literatuurverwysings}

Bauckham, R., 2003, Bible and mission: Christian witness in a postmodern world, Baker Press/Paternoster Press, Grand Rapids/Carlisle.

Bekele, G., 2011, 'The biblical narrative of the missio Dei: Analysis of the interpretive framework of David Bosch's missional hermeneutic', International Bulletin of Missionary Research 35(3), 153-158.

Bennema, C., 2011, 'Spirit and mission in the Bible: Toward a dialogue between biblical studies and missiology', Trinity Journal 32NS, 237-258.

Bird, M.F., 2006, "'A light to the nations" (Isaiah 42:6 and 49:6): Inter-textuality and mission theology in the early church', Reformed Theological Review 65(3), 122-131.

Blackburn, W.R., 2012, The God who makes himself known: The missionary heart of the book of Exodus, InterVarsity Press, Downers Grove. (New Studies in Biblical Theology, 28).

Boda, M.J., 2011, “'Declare his glory among the nations": The psalter as missional collection', in S.E. Porter \& C.L. Westfall (eds.), Christian mission: Old Testament foundations and New Testament developments, pp. 13-40, Pickwick, Eugene.

Bosch, D.J., 1996, Transforming mission: Paradigm shifts in theology of mission, Orbis Books, Maryknoll. (American Society of Missiology, 16).

Carrol Rodas, M.D., 2013, 'Biblical perspectives on migration and mission: Contributions from the Old Testament', Mission Studies 30, 9-26.

Cerny, P., 2010, 'The relationship between theology and missiology: The missiological hermeneutics', European Journal of Theology 19(2), 104-109.

Evans, C.A. 2011, 'A light to the nations: Isaiah and mission in Luke', in S.E. Porter \& C.L. Westfall (eds.), Christian mission: Old Testament foundations and New Testament developments, pp. 93-107, Pickwick, Eugene.
Flemming, D., 2011, 'Exploring a missional reading of Scripture: Philippians as a case study', Evangelical Quarterly 83(1), 3-18.

GKSA, 2006, Handelinge van die nege-en-veertigste Nasionale Sinode van die GKSA, Administratiewe Buro, Potchefstroom.

GKSA, 2009, Handelinge van die Eerste Algemene Sinode van die GKSA, Administratiewe Buro, Potchefstroom.

GKSA, 2012, Handelinge van die Tweede Algemene Sinode van die GKSA, Administratiewe Buro, Potchefstroom.

GKSA, 2015, Handelinge van die Derde Algemene Sinode van die GKSA, Administratiewe Buro, Potchefstroom.

Hogg, W.R., 1988, 'Psalm 22 and Christian mission: A Reflection', International Review of Mission, 77(306), 238-246.

Idestrom, R., 2012, 'The revelation of God's glory as a source of hope: Missio Dei', Tyndale Seminary's Journal of Missional Christianity 5, viewed 7 June 2016, from http://www. missio-dei.ca/2012/10/the-revelation-of-gods-glory-as-a-source-of-hope/

Kaiser, W.C., 2012, Mission in the Old Testament: Israel as a light to the nations, 2nd edn., Baker, Grand Rapids.

Martens, E.A., 1999, 'Ezekiel's contribution to a biblical theology of mission', Direction 28(1), 75-87.

Martens, E.A., 2006, 'Impulses to global mission in Isaiah', Direction 35(1), 59-69.

Nikolajsen, J.B., 2013, 'Missional church: A historical and theological analysis of an ecclesiological tradition', International Review of Mission 102(2), 249-261.

Ott, C., Strauss, S.J. \& Tennent, T.C., 2010, Encountering theology of mission: Biblical foundations, historical developments, and contemporary issues, Baker, Grand Rapids. (Encountering mission).

Tennent, T.C., 2010, Invitation to world missions: A Trinitarian missiology for the twenty-first century, Kregel, Grand Rapids. (Invitation to theological studies).

Van Rooy, H.F., 2012, 'Ezekiel, prophet of the glory of the Lord', in H.G.L. Peels \& S.D. Snyman (eds.), The lion has roared: Theological themes in the prophetic literature of the Old Testament, pp. 127-148, Pickwick, Eugene.

Vicedom, G.F., 2002, Missio Dei, actio Dei, Verlag für Theologie und Religionswissenschaft, Nürnberg. (Edition afem - mission classics, 5)

Waters, L.J., 2009, 'Missio Dei in the book of Job', Bibliotheca Sacra 168, 19-35.

Wright, C.J.H., 2007, The mission of God: Unlocking the Bible's grand narrative, InterVarsity Press, Nottingham.

Wright, C.J.H., 2010, The mission of God's people: A Biblical theology of the church's mission, Zondervan, Grand Rapids. (Biblical theology for life). 